SILVA, GO; BORTOLETTO, AC; CARVALHO, ADF; PEREIRA, AS. 2018. Effect of potassium sources on potato tuber yield and chip quality. Horticultura Brasileira 36: 395-398. DOI - http://dx.doi.org/10.1590/S0102-053620180318

\title{
Effect of potassium sources on potato tuber yield and chip quality
}

\author{
Giovani O Silva ${ }^{1}$; Antonio C Bortoletto ${ }^{1}$; Agnaldo DF Carvalho ${ }^{2}$; Arione S Pereira ${ }^{3}$
}

${ }^{1}$ Embrapa Hortaliças/SIN, Canoinhas-SC, Brazil; giovani.olegario@embrapa.br; antonio.bortoletto@embrapa.br; ${ }^{2}$ Embrapa Hortaliças, Brasília-DF, Brazil; agnaldo.carvalho@embrapa.br; ${ }^{3}$ Embrapa Clima Temperado, Pelotas-RS, Brazil; arione.pereira@embrapa.br

\begin{abstract}
Many potato producers for fry industry changed from the use of potassium chloride to potassium sulfate, as there is a concept that the use of this source improves tuber quality. The aim of this work was to evaluate the effect of these two potassium sources on yield, specific gravity and chip color of potato chipping cultivars. The experiment was carried out on a Dystrophic Red Latosol, in Canoinhas, Brazil, in spring season 2016. Treatments consisted of two potato cultivars, BRSIPR Bel and Atlantic, and two sources of potassium, chloride and sulfate, applied in the furrow at the planting time, in rates based on soil analysis. Experimental design was a randomized complete block in a split-plot arrangement with four replications. Main plots were cultivars and subplots potassium sources. 100 days after planting each sub-plot was evaluated for yield, specific gravity and chip color. There was no significant effect of potassium source on yield components, specific gravity and chip color of BRSIPR Bel and Atlantic.
\end{abstract}

Keywords: Solanum tuberosum, mineral nutrition, fertilizer, BRSIPR Bel, Atlantic.

\section{RESUMO}

Efeito de fontes de potássio na produtividade de tubérculos e qualidade de chips de batata

Muitos produtores de batata para indústria de fritas têm trocado o uso do cloreto de potássio por sulfato de potássio pois há o conceito de que a utilização desta fonte melhora a qualidade dos tubérculos. $\mathrm{O}$ objetivo do presente trabalho foi avaliar o efeito da aplicação dessas fontes de potássio na produtividade, peso específico e cor de fritura de cultivares de batata destinadas ao processamento na forma de chips. O experimento foi realizado em Latossolo Vermelho Distrófico, em Canoinhas-SC, na primavera de 2016. Os tratamentos constaram de duas cultivares de batata, BRSIPR Bel e Atlantic, e duas fontes de potássio, sulfato e cloreto, aplicados no sulco de plantio, em doses baseadas na análise de solo. $\mathrm{O}$ delineamento experimental foi em blocos casualizados, em arranjo de parcelas subdivididas com quatro repetições, com as cultivares compondo as parcelas e as fontes de adubo as subparcelas. Aos 100 dias após o plantio, a produção de tubérculos de cada subparcela foi avaliada em relação ao rendimento de tubérculos, ao peso específico e cor de chips. Não houve efeito significativo do sulfato ou cloreto de potássio, nas variáveis componentes da produção, peso específico e cor de chips das cultivares BRSIPR Bel e Atlantic.

Palavras-chave: Solanum tuberosum, nutrição mineral, fertilizante, BRSIPR Bel, Atlantic.

\section{Received on May 31, 2017; accepted on March 5, 2018}

$\mathrm{P}$ otato crops demand high investment in fertilizers, and depending on price and growing season, it can account for more than $30 \%$ of total crop production cost (Agrianual, 2014). Therefore, there is a need to develop fertilizer management strategies for potato, increasing the efficiency of fertilizer use.

Potato crop is highly responsive to fertilization, which can be attributed to high production potential, short cycle and relatively superficial root system (Fernandes \& Soratto, 2012). However, due to the high potential of response to fertilization, the use of large amounts of fertilizer per unit area has been verified (Queiroz et al., 2013). Often 3 to $4 \mathrm{t}$ $\mathrm{ha}^{-1}$ of formula 04-14-08 (N-P $\left.\mathrm{O}_{5}-\mathrm{K}_{2} \mathrm{O}\right)$ are applied, which is equivalent to 120 to $160 \mathrm{~kg} \mathrm{ha}^{-1}$ of N, 420 to $560 \mathrm{~kg} \mathrm{ha}^{-1}$ of $\mathrm{P}_{2} \mathrm{O}_{5}$ and 240 to $320 \mathrm{~kg} \mathrm{ha}^{-1}$ of $\mathrm{K}_{2} \mathrm{O}$ (Mallmann et al., 2011).

Among the three macronutrients present in traditionally used formulations, potassium is the most absorbed by the crop and essential to obtain high tuber yield (Reis Junior \& Monnerat, 2001). This nutrient is required by plants for the translocation of sugars and starch synthesis, thus influencing the quality of tubers, including dry matter, which is an important characteristic for tubers destined to processing industry (Quadros et al., 2009). Potato tubers with high dry matter content produce crisp potato chips, with less fat absorption (Araujo et al., 2016).

The application of potassium at lower rates than the crop requirement, usually reduces tuber yield and specific gravity, which correlates with dry matter content of tubers (Pauletti \& Menarim, 2004). Therefore, it is very important to determine the potassium requirement to prevent reduction of dry matter content of potato tubers (Reis Júnior \& Fontes, 1996; Reis Junior \& Monnerat, 2001).

In relation to potassium excess in soil and its increased concentration in the plant, there occur a reduction of the osmotic potential and increased water absorption, causing dilution of starch contents and dry matter in the tubers (Stark et al., 2003). The chloride source provides higher potassium uptake in the tuber than the sulfate source, but this effect is dependent on the cultivar 
(Quadros et al., 2009).

Potassium chloride $(\mathrm{KCl})$ is the main potassium source used in fertilization, due to its lower price. However, many producers adopted potassium sulfate $\left(\mathrm{K}_{2} \mathrm{SO}_{4}\right)$ as potassium source, since it is believed to improve tuber quality (Reis Junior \& Monnerat, 2001; Kumar et al., 2007). Many reports mention that potassium sulfate represent superior results regarding vitamin $\mathrm{C}$, ash, carbohydrates, energy and starch, and worse results in relation to tuber water content compared to potassium chloride; but it depends on cultivar (Beringer et al., 1990; Kumar et al., 2007; Quadros et al., 2009). So, the chloride source would have a deleterious effect on potato crop, especially when applied late, since the assimilation of chlorine ion affects combinations with phosphorus, decreasing the carbohydrate synthesis (Quadros et al., 2009). In addition, it slowers translocation of these photoassimilates to tubers in comparison to sulfate source (Kumar et al., 2007). Potassium chloride also raises the salt content that can damage the root system of plants, and consequently their development, besides the possibility of phytotoxicity to chlorine (Grangeiro \& Cecilio Filho, 2004).

This study was installed to evaluate the effect of two potassium sources (chloride and sulfate) on tuber yield and chip quality of two potato cultivars.

\section{MATERIAL AND METHODS}

The experiment was carried out on a Dystrophic Red Latosol (Embrapa, 2006), in Canoinhas $\left(26^{\circ} 10^{\prime} 38^{\prime \prime} \mathrm{S}\right.$, $50^{\circ} 23^{\prime} 24^{\prime \prime} \mathrm{W}, 839 \mathrm{~m}$ altitude), in spring season 2016. Average rainfall from September to December 2015, was, respectively $60.20,198.40,91.60$, and $224.40 \mathrm{~mm}$, while historical average, from 1987 to 2005 , was $152.20,188.20$, 124.20 , and $141.10 \mathrm{~mm}$. Average temperature in these months was, respectively $15.30,17.40,19.10$, and $20.90^{\circ} \mathrm{C}$, while the historical average is $13.40,17.30,19.40$, and $20.90^{\circ} \mathrm{C}$ (Source: Epagri, Ciram).

Soil preparation started one month before planting date, with plowing and flattening. Prior to planting, soil samples were collected from the experimental area, whose analysis revealed the following composition: organic matter $=3.9 \%, \mathrm{pH}(\mathrm{SMP})=4.6, \mathrm{P}=56 \mathrm{mg} \mathrm{dm}^{-3}$, $\mathrm{K}=250 \mathrm{mg} \mathrm{dm}^{-3}, \mathrm{Al}=3.0 \mathrm{cmolc} \mathrm{dm}^{-3}$, $\mathrm{Ca}=2.6 \mathrm{cmolc} \mathrm{dm}^{-3}, \mathrm{Mg}=0.9 \mathrm{cmolc}$ $\mathrm{dm}^{-3}, \mathrm{CTC}=22.6 \mathrm{cmolc} \mathrm{dm}^{-3}, \mathrm{SB}=4.1$ cmolc $\mathrm{dm}^{-3}$ and $\mathrm{V}=18 \%$.

The experimental design was randomized complete block in splitplot arrangement with four replications. Main plots were cultivars and subplots sources of potassium. Plots consisted of two rows each of 25 plants of the same cultivar, spaced $0.75 \mathrm{~m}$ between rows and $0.35 \mathrm{~m}$ between plants.

Treatments consisted of a factorial combining two potassium sources, potassium chloride $\left(\mathrm{KCl}, 60 \%\right.$ of $\left.\mathrm{K}_{2} \mathrm{O}\right)$ and potassium sulfate $\left(\mathrm{K}_{2} \mathrm{SO}_{4} 50 \%\right.$ of $\mathrm{K}_{2} \mathrm{O}$ ), and two potato chipping cultivars recommended: Atlantic, the most used cultivar worldwide for chipping (Webb et al., 1978), and BRSIPR Bel, a cultivar launched by the Brazilian Agricultural Research Corporation (Embrapa) and the Agronomic Institute of Paraná (Iapar) (Pereira et al., 2015).

Potassium sources were applied in the planting furrow at a rate of $140 \mathrm{~kg}$ ha ${ }^{-1}$. In addition, all fertilization of $\mathrm{P}_{2} \mathrm{O}_{5}$ (100 $\left.\mathrm{kg} \mathrm{ha}^{-1}\right)$ as simple superphosphate, and $\mathrm{N}\left(140 \mathrm{~kg} \mathrm{ha}^{-1}\right)$ as ammonium sulfate were applied based on interpretation of soil analysis and recommendations of Silva \& Lopes (2017).

Type II seed tubers that had been cold stored for four months were planted on August 29, 2016. Fifteen days later, earthing up was manually performed. Cultural and phytosanitary treatments followed recommendations for the region (Pereira, 2010).

Plots were harvested 100 days after planting, and tubers were graded as marketable (tuber transversal diameter above $45 \mathrm{~mm}$ ) and non-marketable (tuber transversal diameter equal to or below $45 \mathrm{~mm}$ ), counted and weighted. Specific gravity was measured using a Snack Food Association hydrometer (Silva et al., 2014). Chip color was assessed using three medium sized and healthy tuber samples, cut transversely in slices, fried in vegetable oil at an initial temperature of $180^{\circ} \mathrm{C}$ until bubbling stopped, then scored for color using a 1 to 9 grade scale ( $1=$ dark, $9=$ light), adapted from Silva et al. (2014).

Tuber yield data were transformed to t ha ${ }^{-1}$, and number of tubers to number $\mathrm{ha}^{-1} / 1000$. Data were checked for normal distribution of residues by the Lilliefors test, submitted to analysis of variance, and means compared with the use of the $t$ test, using the program Genes (Cruz, 2013).

\section{RESULTS AND DISCUSSION}

According to meteorological data, the average temperatures of the growing season were very similar to historical average temperature for the region. Rainfall averages were also normal for the season, and well distributed. Precipitation in the first month was below historical average. But, it is known that until the 30 days after planting, the potato crop does not need large water volumes, as there is enough reserve in the tubers. According to Pereira (1991), during this period, about $1.66 \mathrm{~mm}$ daily are necessary, which is less than the close $2 \mathrm{~mm}$ daily observed in the period. In November, rainfall was slightly below historical average, but it was well distributed during the month. In the period of tuber bulking and maturation, $2.81 \mathrm{~mm}$ daily is necessary (Pereira, 1991), which was less than the $3.05 \mathrm{~mm}$ observed in this study. And in December, the amount of rain was above average, but the greater amount occurred later in the month, when the experiment had already been harvested. So, it is confirmed that the meteorological conditions for the period were adequate for good plant development.

The analysis of variance revealed significant differences $(\mathrm{p} \leq 0.05)$ among cultivars for marketable tubers, number of tubers, mass of non-marketable tubers, and specific gravity. There were no differences for other traits, as well as for potassium sources and cultivar $\mathrm{x}$ potassium source interaction (Table 1).

'Atlantic' was more productive than 'BRSIPR Bel', presenting larger tubers, therefore classified in greater proportion as marketable. This cultivar also had higher specific gravity (Table 
Table 1. Means and $p$ statistic for yield, specific gravity and chip color for two potato cultivars BRSIPR Bel and Atlantic, as function of two potassium fertilizers sources, potassium sulfate $\left(\mathrm{K}_{2} \mathrm{SO}_{4}\right)$ and potassium chloride $(\mathrm{KCl})$, in spring 2016, in Canoinhas. Canoinhas, Embrapa, 2017.

\begin{tabular}{|c|c|c|c|c|c|c|c|c|}
\hline \multirow{2}{*}{ Evaluations } & NMT $^{1}$ & NNMT & TNT & MMT & MNMT & TTM & \multirow{2}{*}{ SG } & \multirow{2}{*}{ Cor** } \\
\hline & \multicolumn{3}{|c|}{$\left(\mathrm{ha}^{-1 / 1000)}\right.$} & \multicolumn{3}{|c|}{$\left(\mathrm{t} \mathrm{ha}^{-1}\right)$} & & \\
\hline BRSIPR Bel & $61.17 \mathrm{a}$ & $237.23 \mathrm{a}$ & $298.40 \mathrm{a}$ & $11.78 \mathrm{~b}$ & $16.16 \mathrm{a}$ & $27.93 \mathrm{a}$ & $1.080 \mathrm{~b}$ & $7.50 \mathrm{a}$ \\
\hline Atlantic & $89.11 \mathrm{a}$ & $107.57 \mathrm{~b}$ & $196.68 \mathrm{a}$ & $18.37 \mathrm{a}$ & $8.94 \mathrm{~b}$ & $27.32 \mathrm{a}$ & $1.090 \mathrm{a}$ & $6.88 \mathrm{a}$ \\
\hline $\mathrm{K}_{2} \mathrm{SO}_{4}$ & $72.62 \mathrm{a}$ & $167.35 \mathrm{a}$ & $239.96 \mathrm{a}$ & $14.95 \mathrm{a}$ & $12.22 \mathrm{a}$ & $27.17 \mathrm{a}$ & $1.084 \mathrm{a}$ & $7.25 \mathrm{a}$ \\
\hline \multirow[t]{2}{*}{$\mathrm{KCl}$} & $77.65 \mathrm{a}$ & $177.45 \mathrm{a}$ & $255.11 \mathrm{a}$ & $15.19 \mathrm{a}$ & $12.88 \mathrm{a}$ & $28.07 \mathrm{a}$ & $1.082 \mathrm{a}$ & $7.12 \mathrm{a}$ \\
\hline & \multicolumn{8}{|c|}{$p$ STATISTIC } \\
\hline Cultivars & $12.74^{\mathrm{ns}}$ & $1.96^{*}$ & $6.65^{\mathrm{ns}}$ & $4.46^{*}$ & $3.32 *$ & $100.00^{\text {ns }}$ & $0.66^{*}$ & $39.10^{\mathrm{ns}}$ \\
\hline Fertilizer & $100.00^{\text {ns }}$ & $100.00^{\text {ns }}$ & $100.00^{\mathrm{ns}}$ & $100.00^{\mathrm{ns}}$ & $28.18^{\mathrm{ns}}$ & $100.00^{\text {ns }}$ & $12.75^{\mathrm{ns}}$ & $100.00^{\mathrm{ns}}$ \\
\hline $\begin{array}{l}\text { Fertilizer x } \\
\text { cultivar }\end{array}$ & $100.00^{\text {ns }}$ & $100.00^{\text {ns }}$ & $100.00^{\text {ns }}$ & $100.00^{\text {ns }}$ & $100.00^{\text {ns }}$ & $100.00^{\text {ns }}$ & $100.00^{\text {ns }}$ & $100.00^{\mathrm{ns}}$ \\
\hline General mean & 75.14 & 172.40 & 247.54 & 15.08 & 12.55 & 27.63 & 1.083 & 7.19 \\
\hline CV cultivar $(\%)$ & 35.53 & 32.86 & 29.10 & 26.25 & 30.70 & 27.96 & 0.11 & 17.39 \\
\hline CV fertilizer(\%) & 19.64 & 31.55 & 26.88 & 18.58 & 8.84 & 13.30 & 0.18 & 11.88 \\
\hline
\end{tabular}

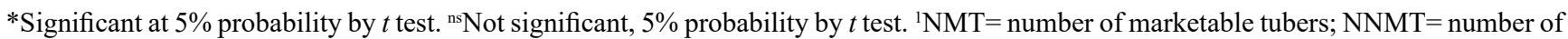
non-marketable tubers; TNT= total number of tubers; MMT= mass of marketable tubers; MNMT= mass of non-marketable tubers; TTM= total tuber mass; $\mathrm{SG}=$ specific gravity; Cor= chip color. $* *$ notes from 1 (dark color) to 9 (light color).

1), therefore, better frying quality, since higher specific gravity is related to higher dry matter content, which provides lower fat absorption during frying and higher crispness (Araujo et al., 2016).

Being there no significant cultivar $\mathrm{x}$ potassium interaction, the discussion of this study was based on average of the two cultivars. According to table 1 , total yield mean of cultivars and potassium sources was $27.63 \mathrm{t} \mathrm{ha}^{-1}$, while the mean yield of marketable tubers was 11.78 t ha $^{-1}$ for 'BRSIPR Bel' and $18.37 \mathrm{tha}^{-1}$ for 'Atlantic'. In winter crop in Itai-SP, in a soil similar to the present study, Fernandes et al. (2011) reported total yield of $22.54 \mathrm{t} \mathrm{ha}^{-1}$ and yield of marketable tubers of $17.71 \mathrm{t}$ ha $^{-1}$ for'Atlantic'. In spring 2010 and 2011, in Canoinhas, Pereira et al. (2015) reported average of the two crops for same cultivars used in this study, 28.52 $\mathrm{t} \mathrm{ha}^{-1}$ for total yield and $15.70 \mathrm{t} \mathrm{ha}^{-1}$ for marketable yield. Such values are very close to those observed in the present study, indicating that the experimental and environmental conditions had been normal.

The average specific gravity of 1.083 , equivalent to $20.85 \%$ of dry matter, meets the ideal minimum (20\%) for chipping (Araujo et al., 2016).

In the present study potassium rate was based on recommendation of Silva \& Lopes (2017), which is lower than that used by some producers in different regions of the country. They apply $3.0 \mathrm{t} \mathrm{ha}^{-1}$ of the formula $04-14-08$ (N-P $\mathrm{O}_{5}-\mathrm{K}_{2} \mathrm{O}$ ), which represents $71 \%$ of the recommended rate used in the present study. According to Oliveira (2013), the effects of these two sources of potassium on tuber quality are more visible in excessive rates.

The potato crop is very responsive to fertilization (Nava et al., 2007). For high yields, nutrient extraction is relatively high and for the production of $1.0 \mathrm{t} \mathrm{ha}^{-1}$ of tubers, approximately $8.0 \mathrm{~kg}$ of $\mathrm{K}_{2} \mathrm{O}, 5.3 \mathrm{~kg}$ of $\mathrm{N}$ and $1.2 \mathrm{~kg}$ of $\mathrm{P}_{2} \mathrm{O}_{5}$ are extracted (Nava et al., 2007). For cultivar Monalisa, in Pinhão-PR, the maximum net revenue was obtained with the increase of $320 \mathrm{~kg}$ of $\mathrm{K}_{2} \mathrm{O}$ in the traditional $3 \mathrm{t} \mathrm{ha}^{-1}$ rate of $04-14-08$, and to supply all the potassium need with this formulation, it would require $7.0 \mathrm{t}$ ha $^{-1}$ of fertilizer (Mallmann et al., 2011). However, excessive rates should be avoided, as they may reduce economic sustainability, by having a great impact on the production cost (Fernandes $\&$ Soratto, 2013), the environmental sustainability (Reis Junior \& Monnerat, 2001) and tuber quality (Junior \& Fontes, 1996).

For these experimental conditions, potassium sources, sulfate or chloride, showed no effect on tuber yield components, specific gravity and chip color of cultivars BRSIPR Bel and Atlantic.

\section{REFERENCES}

AGRIANUAL - Anuário da Agricultura Brasileira. 2014. Batata. São Paulo: FNP. 463p.

ARAÚJO, TH; PÁDUA, JG; SPOTO, MHF; ORTIZ, VDG; MARGOSSIAN, PL; DIAS, CTS; MELO, PCT. 2016. Productivity and quality of potato cultivars for processing as shoestrings and chips. Horticultura Brasileira 34: $554-560$.

BERINGER, H; KOCH, K; LINDHAUER, MG. 1990. Source:sink relationship in potato (Solanum tuberosum) as influenced by potassium chloride or potassium sulphate nutrition. Plant and Soil 124: 287-290.

CRUZ, CD. 2013. Genes; a software package for analysis in experimental statistics and quantitative genetics. Acta Scientiarum Agronomy 35: 271-276.

EMBRAPA. Centro Nacional de Pesquisa de Solos. 2006. Sistema brasileiro de classificação de solos. 2 ed. Brasília: Embrapa. 306p.

FERNANDES, AM; SORATTO, RP; EVANGELISTA, RM; SILVA, BL; SOUZASCHLICK, GD. 2011. Produtividade e 
esverdeamento pós-colheita de tubérculos de cultivares de batata produzidos na safra de inverno. Revista Ciência Agronômica 42: 502-508.

FERNANDES, AM; SORATTO, RP. 2012. Nutrição mineral, calagem e adubação da batateira. Botucatu: Editora Fepaf. 121p.

FERNANDES, AM; SORATTO, RP. 2013. Eficiência de utilização de nutrientes por cultivares de batata. Bioscience Journal 29: 91-100.

GRANGEIRO, LC; CECÍlIO FILHO, AB. 2004. Exportação de nutrientes pelos frutos de melancia em função de épocas de cultivo, fontes e doses de potássio. Horticultura Brasileira 22: 740-743.

KUMAR, P; PANDEY, SK; SINGH, BP; SINGH, SV; KUMAR, D. 2007. Influence of source and time of potassium application on potato growth, yield, economics and crisp quality. Potato Research 50: 1-13.

MALLMANN, N; LUCCHESI, LAC; DESCHAMPS, C. 2011. Influência da adubação com NPK na produção comercial e rentabilidade da batata na região CentroOeste do Paraná. Pesquisa Aplicada \& Agrotecnologia 4: 67-74.

NAVA, G; DECHEN, AR; IUCHI, VL. 2007. Produção de tubérculos de batata-semente em função das adubações nitrogenada, fosfatada e potássica. Horticultura Brasileira 25: 365-370.

OLIVEIRA, RC. 2013. Acúmulo de nutrientes. produtividade e qualidade de batata, $c v$. Asterix, sob fontes de fertilizantes potássicos. Uberlândia: UFU. 75p. (Ph.D. thesis).

PAULETTI, V; MENARIN, E. 2004. Época de aplicação, fontes e doses de potássio na cultura da batata. Scientia Agraria 5: 15-20.

PEREIRA, AB. 1991. Demanda climática ideal de água e produtividade da cultura de batata (Solanum tuberosum L. Cv. Itararé). Botucatu: UNESP-FCA. 97p. (Ph.D. thesis).

PEREIRA, AS. (org). 2010. Produção de batata no Rio Grande do Sul. Sistema de Produção, 19. Pelotas: Embrapa Clima Temperado. 95p.

PEREIRA, AS; NAZARENO, NRX; SILVA, GO; BERTONCINI, O; CASTRO, CM; HIRANO, E; BORTOLETTO, AC; TREPTOW, RO; DUTRA, LF; LIMA, MF; GOMES, CB; KROLOW, ACR; MEDEIROS, CAB; CASTRO, LAS; SUINAGA, FA; LOPES, CA; MELO, PE. 2015. BRSIPR Bel: Cultivar de batata para chips com tubérculos de boa aparência. Horticultura Brasileira 33: 135139.

QUADROS, DA; IUNG, MC; FERREIRA, SMR; FREITAS, RJS. 2009. Composição química de tubérculos de batata para processamento, cultivados sob diferentes doses e fontes de potássio. Ciência e Tecnologia de Alimentos 29: 316-323.

QUEIROZ, LRM; KAWAKAMI, J; MULLER, MML; OLIARI, ICR; UMBURANAS, RC; ESCHEMBACK, V. 2013. Adubação NPK e tamanho da batata-semente no crescimento, produtividade e rentabilidade de plantas de batata. Horticultura Brasileira 31: 119-127.

REIS JÚNIOR, RA; FONTES, PCR. 1996. Qualidade de tubérculos de batata em função de doses da adubação potássica. Horticultura Brasileira 14: 170-174.

REIS JÚNIOR, RA; MONNERAT, PH. 2001. Exportação de nutrientes nos tubérculos de batata em função de doses de sulfato de potássio. Horticultura Brasileira 19: 227-231.

SILVA, GO; PEREIRA, AS; SUINAGA, FA; PONIJALEKI, R. 2014. Seleção de clones de batata para fritura com base em índices de seleção. Revista Ceres 61: 941-947.

SILVA, GO; LOPES, CA. 2017, October, 17. Sistema de produção da batata. Available at https://www.spo.cnptia.embrapa.br/temaspublicados

STARK, JC; OLSEN, N; KLEINKOPF, GE; LOVE, SL. 2003. Tuber quality. In: STARK, JC; LOVE, SL (eds). Potato production systems. Idaho: Idaho Center for Potato Research \& Education. 420p. Available at http://www.ag.uidaho.edu/potato/production/. Accessed March15, 2017.

WEBB, RE; WILSON, DR; SHUMAKER, JR; GRAVES, B; HENNINGER, MR; WATTS, J; FRANK, JA; MURPHY, HJ. 1978. Atlantic: a new potato variety with high solids, good processing quality, and resistance to pests. American Potato Journal 55: 141-145. 